Volume 13 Number 3, July-September 2019: pp. 271-288. Copyright (c) 2019 FIAT JUSTISIA. Faculty of Law, Lampung University, Bandarlampung, Lampung, Indonesia. ISSN: 1978-5186 | e-ISSN: 2477-6238.Open Access: http://jurnal.fh.unila.ac.id/index.php/fiat

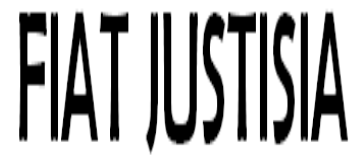

Fiat Justisia is licensed under a Creative Commons Attribution 4.0 International License, which permits unrestricted use, distribution, and reproduction in any medium, provided the original work is properly cited.

\title{
The Existence of a Regulatory Sandbox to Encourage the Growth of Financial Technology in Indonesia
}

\author{
Recca Ayu Hapsari \\ Universitas Bandar Lampung, Indonesia \\ recca@ubl.ac.id \\ Maroni \\ Universitas Lampung, Indonesia \\ maroniunila@gmail.com \\ Indah Satria \\ Universitas Bandar Lampung, Indonesia \\ indah.satria@ubl.ac.id \\ Nenny Dwi Ariani \\ Universitas Lampung, Indonesia \\ nennydwiariani@gmail.com
}

\begin{abstract}
Bank Indonesia created an appropriate regulatory regime to drive the pace of innovation carried out by Financial Technology Providers while still applying the principles of consumer protection, risk management and prudence. One of the efforts made by Bank Indonesia was by issuing provisions concerning a regulatory sandbox for Financial Technology Providers along with their products, services, technology and/or business models in a Board of Governors Member Regulation No 19/14/PADG/2017 on the Limited Technology Testing Room (Regulatory Sandbox) Financial Technology. Meanwhile, the Financial Services Authority also issued regulation regarding the Regulatory Sandbox for Financial Technology Organizers in Financial Services Authority Regulation No. 13 / POJK.02/2018 on the Digital Financial Innovations in the Financial Services Sector. The main point of view to be analyzed is the existence of
\end{abstract}


regulatory sandbox approach held by Bank Indonesia and the Financial Services Authority as an effort to encourage the growth of Financial Technology in Indonesia.

Keyword: Regulatory Sandbox, Financial Technology, Bank Indonesia, Financial Services Authority

How to Cite: Recca Ayu Hapsari, Maroni, Indah Satria, Nenny Dwi Ariani, "The Existence of a Regulatory Sandbox to Encourage the Growth of Financial Technology in Indonesia", Fiat Justisia, 13 (3), (2019).

DOI: 10.25041/fiatjustisia.v13no3.1739

\section{A. Introduction}

The era of economic digitalisation triggered the use of internet technology, smartphones, and big data to help consumers more efficiently, both in terms of time, access, and cost. In this context, the flow of digitalisation of the economy including Financial Technology (FinTech) has great potential to encourage more efficient allocation of economic resources and in turn encourage increased productivity and provide greater benefits for the community.

That developments and innovations in the financial technology industry need to be mitigated both appropriately and adequately in order to provide benefits to the society and economy. In this regard, Bank Indonesia created a convenient regulatory regime to be able to drive the pace of innovation carried out by Financial Technology Providers while still applying the principles of consumer protection, risk management and prudence. One of the efforts made by Bank Indonesia was by issuing provisions concerning a regulatory sandbox for Financial Technology Providers along with their products, services, technologies and/or business models in a Board of Governors Member Regulation No.19/14/PADG/2017 on the Limited Technology Testing Room (Regulatory Sandbox) Financial Technology (PADG 19). As well as supporting the implementation of that Financial Technology, Bank Indonesia issued Bank Indonesia Regulation No 19/12/PBI/2017 on the Implementation of Financial Technology (PBI 19). In addition to Bank Indonesia, the Financial Services Authority also issued regulation regarding the Regulatory Sandbox for Financial Technology Organizers in Financial Services Authority Regulation No. 13 / POJK.02/2018 on the Digital Financial Innovations in the Financial Services Sector (POJK 13).

Based on Article 1 paragraph (4) of PADG 19, the term of Regulatory Sandbox is a safe limited trial space for testing Providers of Financial 
Technology and its products, services, technology and / or business models. Meanwhile, based on Article 1 paragraph (4) of POJK 13, the understanding of the Regulatory Sandbox is a testing mechanism carried out by the Financial Services Authority to assess the reliability of business processes, business models, financial instruments, and Organizer governance. Meanwhile, based on Article 1 paragraph (4) of POJK 13, the definition of the Regulatory Sandbox is a testing mechanism carried out by the Financial Services Authority to assess the reliability of business processes, business models, financial instruments, and organiser governance.

The regulatory sandbox's concept is a selection process for a fintech concept that started from the United Kingdom and is followed by other countries that have advanced in fintech such as the United States (US), Australia, China and Singapore. The regulatory sandbox principle throughout the world has the same goal, namely the learning and testing process. The next goal is to provide time for innovators to make improvements and improve governance and business risk. Ivo Jenik and Kate Launer in their journal, published by The Consultative Group to Assist the Poor (CGAP) in October 2017, said that the framework for trials was first compiled by the US Bureau of Finance and Consumer Protection (Consumer Financial Protection Bureau (CFPB) below the name Project Catalyst. The UK Financial Settings Authority (FCA) first coined the term 2015 regulatory sandbox. Since then, the organisational sandbox concept has spread to more than 20 countries in the world. ${ }^{1}$

The UK's Financial Conduct Authority (FCA) launched a regulation regarding regulatory sandbox for the fintech platform globally in 2016, following the 2015 national regulatory sandbox success. The rule allows the development of innovative fintech without a strict regulatory process for the trial phase. The FCA said the potential benefits of regulatory sandbox include adequate time and costs for creative testing ideas on the market, providing innovators with broader access, allowing more potentially popular market-tested products, enabling collaboration between FCA and innovators to ensuring the right consumer market, as well as protection of new products and services. The regulatory sandbox application was opened in June 2016, and from 146 innovators who applied, there were 50 innovators or business ideas received and 41 other applicants in the process of being tested. Launching Forbes, the state of Arizona became the first state in the US to adopt a regulatory sandbox to develop business industries including fintech, block chain and crypto currency. Fintech companies that are included in the regulatory sandbox can test products for up to two years and serve 10,000

\footnotetext{
${ }^{1}$ Ivo Jenik and Kate Lauer, Regulatory Sandboxes and financial Inclusion, Working Paper, Washington DC: CGAP, (2017), p. 1.
} 
customers before finally applying for an official permit. Doug Ducey, Governor of Arizona, revealed that with the signing of H.B 2434 becoming law at AZTech 2018, Arizona has a regulatory sandbox for the development of the fintech industry. ${ }^{2}$

As explained in the PADG 19, to encourage the development of innovation in activities that use financial technology, a limited trial space for financial technology providers and products should be provided, services, technology and/or business models, that apply the principles of consumer protection and risk management and prudence. The trial process in the Regulatory Sandbox applies the principle of criteria-based operation, transparency, proportionality, fairness, equality and forward-looking. On the other hand, through POJK 13, the Financial Services Authority (OJK) provides the main reason for establishing the Regulatory Sandbox is as a means to bring together industry players with regulators. Through this forum, authorities will identify and observe the dynamics and risks of digital market financial services. With an understanding of the new business model, authorities can determine mitigation efforts to maintain financial system stability.

A total of 67 Financial Technology companies that have been recorded in the Financial Services Authority will enter the regulatory sandbox test laboratory in February 2019 to get a recommendation for eligibility to obtain permission. ${ }^{3}$

Bank Indonesia (BI) and the Financial Services Authority (FSA) apply regulatory sandbox provisions or pilot programs for startup companies in the field of technology-based financial services (financial technology). This program is a trial place for fintech companies before operating to serve the community. This regulatory sandbox in FSA has a different function than the regulatory sandbox at Bank Indonesia. The FSA Regulatory Sandbox focuses on financial services, both banking and non-bank products. While the regulatory sandbox at BI handles products related to payment system services. If the digital business industry carries out activities under the supervision of the FSA, FSA will be handed over. Whereas for those related to the payment system, it is BI's regulatory sandbox. ${ }^{4}$

In terms of scope of supervision, those two institutions have different authority. BI has the power to test fintech companies with e-payment systems, such as Go-Pay. Whereas, FSA has the right to evaluate fintech of

\footnotetext{
2 Dea Chadiza Syafina, 2018, "Mengenal Regulatory Sandbox, Rahim dari Kelahiran Para Fintech", https://tirto.id/mengenal-regulatory-sandbox-rahim-dari-kelahiran-para-fintech$\mathrm{cJpW}$.

3 https://economy.okezone.com/read/2019/01/29/320/2010778/67-perusahaan-fintech-ujikelayakan-untuk-dapat-izin-ojk .

${ }^{4}$ Ibid.
} 
financial services such as crowdfunding (financing), peer to peer lending (technology-based money lending and borrowing services). To participate in the regulatory sandbox program, fintech companies must register with the regulator first.

Furthermore, the company follows several stages of assessment. For example, the assessment of internal conditions such as management profiles and the reputation of the management, the novelty and benefits of products, funding and legal consultants. Also, regulators assess the company's outer side, such as business competition and consumer protection, information, education, and consumer dispute resolution.

Through this regulatory sandbox process, regulators can find out the conditions of management and products offered by fintech companies. After conducting various stages of assessment, the regulator is authorised to state the feasibility of the company.

Based on BI's regulation on Regulatory Sandbox, it is stated that BI can set a certain period for fintech companies to conduct a trial in a regulatory sandbox with a maximum limit of 12 months. After the expiration period, BI determines the status of the results of the fintech company trial with three criteria namely successful, unsuccessful, or other status determined by BI. For those who succeed in the trial, then the fintech company can offer its products to the community by applying for permission to BI first. The successful statement from BI influences the level of consumer confidence in the fintech company. Whereas, companies that do not succeed in passing the regulatory sandbox, are prohibited from marketing the products, services, technology and or business models that are tested. The duration of the regulatory sandbox trial is set at no later than six months from the date of stipulation of the product, service, technology and business model trial scenario. The period can be extended once for a maximum of six months. So, the total time that the fintech company can use is testing the product to be a year.

During the implementation of the trial, fintech companies must ensure adequate application of the principles of consumer protection, risk management and prudence. The company is also required to submit a trial implementation report, both regularly and incidentally by BI's request. BI data in early April, only 1 out of 15 fintech companies registered to follow the regulatory sandbox process, namely PT. Toko Pandai Nusantara (Toko Pandai). This company is considered to have fulfilled eight BI criteria to support the trial process as stipulated in Article 3 of Bank Indonesia Regulation No 19/14/PADG/2017.

The concept of a limited trial room (Regulatory Sandbox) for financial technology has the potential to create business risks. One such chance was when the central bank authorities stated that Fintech organisers "did not 
succeed" in the implementation of limited trials. Fintech providers of the payment system when setting in the Regulatory Sandbox are still allowed to operate, but the company is under certain supervision by the central bank. In other words, the central bank still allows fintech to operate, but the activities carried out are limited as determined by BI. Bank Indonesia through PADG 19 regulates that the central bank can set up a fintech operator along with its products, services, technology, and business models to be tested in the Regulatory Sandbox as long as it meets criteria according to Article 3 paragraph (2) the rules are innovative, have an impact on products, services, technology and financial business models that already exist, provide benefits to the community, can be used widely, and other criteria set by the central bank. After the trial period turned out that the central bank determined the results of the trial were unsuccessful, fintech organizers were prohibited from marketing their products and / or services and using technology and business models. Meanwhile, Article 8 paragraph (2) of POJK 13 determine the eligibility of criteria that can be tested in the Sanul Regulatory namely registered at the Financial Services Authority or based on an application letter submitted by the relevant supervisory work unit at the Financial Services Authority, is a new business model, has a business scale with broad market coverage, is registered in the Association of the Provider and other criteria set by the Financial Services Authority.

Based on the background, the main point of view to be analyzed is the existence of regulatory sandbox approach held by Bank Indonesia and the Financial Services Authority as an effort to encourage the growth of financial technology in Indonesia. As for the problems, in this case, are as follows: How is the regulatory sandbox approach held by Bank Indonesia and the Financial Services Authority? How to encourage the growth of financial technology in Indonesia through the regulatory sandbox approach?

\section{B. Research methods}

In this research used normative or doctrinal juridical methods, which are intended as legal research conducted by examining library materials or secondary data consisting of primary legal materials, secondary legal materials, and tertiary legal materials. The approach used in legal research is the statute approach, the comparative approach, and the analytical approach. The data analysis technique in this research uses content analysis, which is a series of methods for analysing the contents of all forms of communication by reducing the entire contents of communication into a series of categories that represent the things to be studied. 


\section{Discussion}

\section{The Regulatory Sandbox Approach by Bank Indonesia and the Financial Services Authority}

The UK pioneered this sandbox model setting as a regulatory sandbox or a trial program for FinTech start-ups. The purpose of the sandbox is for FinTech players to test their systems and businesses with a span of 6 months to 12 months before the market is fully operational. In this trial period, the FinTech company will be accompanied by the government in a legal and operational administration system, so that there are no rules violated by the FinTech company. The primary key to the success of the sandbox system lies in government assistance. Therefore, the sandbox is just a program name that aims to develop FinTech companies. Through legal aid and technical assistance, FinTech will be tested before operating in the community. After mentoring then the government sets operational permits and service standards. The primary purpose of the sandbox program is to get the public trust that FinTech is born will be safe in operation. With the public trust, of course there will be more users. It shows that UK financial legal instruments are designed in such a market-oriented way. ${ }^{5}$

As explained the flow of assistance carried out by the Financial Conduct Authority (FCAS) as an institution committed to promoting effective competition in financial services regulated in the interests of consumers. The definition of the regulatory sandbox, according to the FCA, is:

A regulatory sandbox is a 'safe space' in which businesses can test innovative products, services, business models and delivery mechanisms without immediately incurring all the usual regulatory consequences of engaging in the activity in question. The exact firm journey and the FCA's involvement will depend on the specific options used, the regulatory status of the firm, the solution being tested and the extent of consumer involvement. The below chart 1 is an outline of the 'firm journey' for options that can be implemented by the FCA. ${ }^{6}$

\footnotetext{
${ }^{5}$ Bambang Pratama, 2017 Mengenal Regulatory Sandbox Pada Fintech, Rubric of Faculty Members, Binus University Faculty Of Humanities, https://businesslaw.binus.ac.id/2016/09/29/mengenal-regulatory-Sandbox-pada-fintech/.

6 https://www.fca.org.uk/publication/research/regulatory-sandbox.pdf, accessed in Bandar Lampung on $27-07-2018$
} 


\section{Firm journey}

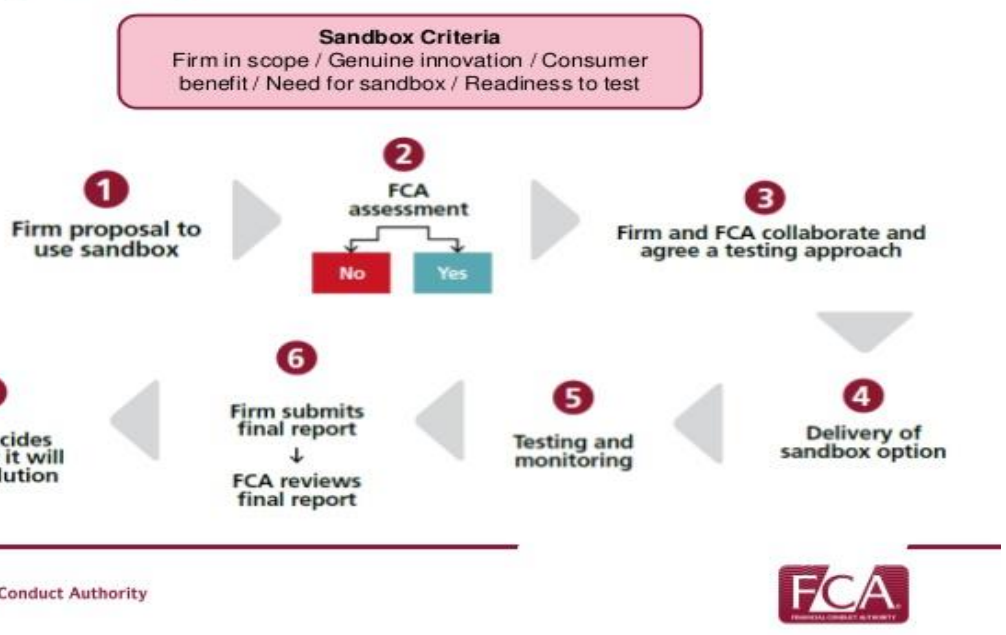

The concept and implementation of the regulatory sandbox has evolved by looking at different models, many of which follow FCA blueprint as a reference, they have the following designs;

Despite the diversity, many regulatory sandboxes follow the FCA's blueprint, and therefore, they have the following design components:

Objectives of the sandbox?

a) Eligibility to apply to the sandbox.

b) Criteria (specified in the application) regarding risks, safeguards, and other restrictions.

c) Timing for applicants and sandbox entities tests.

d) Costs to the regulator and the sandbox entities.

e) Regulator's actions following the sandbox test $(s)$

Some anticipatory legal steps to deal with the Fintech phenomenon are by making a regulatory sandbox. In general, the regulatory sandbox was used as a testing lab for Fintech actors before the business was released to the market. Generally, regulatory sandboxes are held by the Central Bank (Bank Indonesia), but there are some countries whose Central Banks work with research institutions and/or universities.

The government, through the Financial Services Authority (FSA), has issued FSA Regulation (POJK) No. 13 / POJK.02 / 2018 on the Digital Financial Innovation in the Financial Services Sector (POJK 13). That based on Article 1 POJK 13, the Regulatory Sandbox is a mechanism of testing

${ }^{7}$ Ivo Jenik and Kate Lauer, Loc.Cit. 
carried out by the Financial Services Authority to assess the reliability of business processes, business models, financial instruments and governance of the Operator. Whereas according to the Board of Governors' Member Regulation No.19/14/PADG/2017 concerning Limited Testing Room (Regulatory Sandbox) of Financial Technology, the definition of Regulatory Sandbox is a safe limited testing room to test Financial Technology Organizers along with products, services, technology, and/or business model.

Through POJK 13, that every organiser of Digital Financial Innovation (IKD), both start up companies and Financial Service Institutions (LJK), will go through three stages of the process before submitting a licensing application. First is the recording phase to OJK for start up/non-LJK companies. Application for recording automatically includes a request for testing the Regulatory Sandbox. As for LJK, the Sandbox application is submitted to supervisors in each field (Banking, Capital Market, IKNB). Second, the Regulatory Sandbox Process has a maximum period of one year and can be extended for six months if needed. Third, after passing through the Regulatory Sandbox process with a "recommended" status, it can be continued with registration/licensing to the FSA. In the Regulatory Sandbox process, registered fintech companies are required to submit periodic performance reports quarterly to the FSA. That based on Article 9 POJK 13 the Regulatory Sandbox is implemented in a maximum period of 1 (one) year and can be extended for 6 (six) months if necessary. A little faster, the trial period in the Regulatory Sandbox conducted by Bank Indonesia is for 6 months and can be extended one time at the latest 6 months. In PADG 19, the Operator is required to make a presentation to $\mathrm{BI}$ regarding the business model and risk management along with complete documents. Both PADG 19 and POJK 13 regulate consumer protection requirements. During the trial period in the Sandbox Regulatory, fintech operators were obliged to ensure the application of the principles of consumer protection and adequate risk management and prudence (Article 13 PADG 19), including in protecting data, information, and consumer funds.

Whereas in POJK, 13 Organizers are required to maintain confidentiality, integrity and availability of personal data, transaction data, and financial data they manage since the data is obtained until the data is destroyed. The media and methods used in obtaining data and information must also be guaranteed confidentiality, security, and integrity. If you want to handle user data and information, the organiser must obtain approval from the user. The organiser must also convey the limits on the use of data and information to the user, including if there is a change in the purpose of using this matter. 
Next, the authors describe the analysis of differences in the implementation of the regulatory sandbox between the Financial Services Authority Institution through FSA Regulation (POJK) No. 13 / POJK.02 / 2018 and Bank Indonesia through the Board of Governors' Member Regulation No.19/14/PADG/2017, as follows:

a. The period required to carry out the regulatory sandbox, OJK Regulation (POJK) No.13/POJK.02/2018 Article 9, Regulatory Sandbox is implemented for a maximum period of 1 (one) year and can be extended for 6 (six) months if necessary. Article 11 of the Regulation of the Board of Governors No.19/14/PADG/2017 stated that the period of trial in the Regulatory Sandbox is set at no later than 6 (six) months from the date Bank Indonesia determines the product, service, technology and / or model trial scenario. Business. Analysis of the Implementation of the Regulatory Sandbox by BI is faster.

b. Basic Principles of Regulatory Sandbox, OJK Regulation (POJK) No. 13/POJK.02/2018, Article 7, Article 4,

1) Innovative and forward-oriented;

2) Use information and communication technology as the primary means of providing services to consumers in the financial services sector;

3) Support financial inclusion and literacy;

4) Useful and can be used widely;

5) Can be integrated into existing financial services;

6) Using a collaborative approach; and

7) Pay attention to aspects of consumer protection and data protection. Article 8 of Regulation of the Board of Governors No.19/14/PADG/2017, the trial process in the Regulatory Sandbox applies the principle:

1) Criteria-based process; The determination of the participants of the Sandbox Regulatory takes into account the fulfilment of criteria set by Bank Indonesia.

2) Transparency; Announcement of the results of the Sandbox Regulatory periodically.

3) Proportionality; Consider the type, scale, and risk of the tested products, services, technologies and/or business models.

4) Fairness; Financial Technology Providers have the same opportunity as long as they meet the criteria of Bank Indonesia.

5) Equality (equal treatment); Provisions regarding the Regulatory Sandbox apply to all Financial Technology Administrators.

6) Forward-looking; Consider the future potential and benefits to society and the economy. 
The basic principles of the Regulatory Sandbox used by BI and OJK are almost similar, namely in the form of innovative, transparent, proportional, benefits, legal protection and legal justice principles.

c. Fintech tested, OJK Regulation (POJK) No. 13 / POJK.02 / 2018, Article 5, the Operator consists of:

1) Financial Services Institution; and / or

2) Other parties that carry out activities in the financial services sector.

Regulation of the Board of Governors No.19/14/PADG/2017, Article 3 Paragraph (2) letter b, Financial Technology held contains elements that can be categorized into the payment system. There are differences in the fintech sector being tested in each institution, so there is no overlapping in the implementation of the regulatory sandbox.

d. Trial Results in the Regulatory Sandbox, OJK Regulation (POJK) No. 13/POJK.02/2018, Article 11 Paragraph (1), the Regulatory Sandbox Results against the Operator are stated by status:

1) Recommended;

2) Improvement; or

3) Not Recommended.

Regulation of the Board of Governors No.19/14/PADG/2017, Article 16 Paragraph (3), Bank Indonesia stipulates the status of the trial results in the Regulatory Sandbox, namely:

1) Succeeded;

2) Not successful; or

3) Other status stipulated by Bank Indonesia.

e. Follow-up on the results of the trial test in the Regulatory Sandbox, FSA Regulation (POJK) No.13/POJK.02/2018, Article 11 Paragraph (2);

If the Operator is recommended as referred to in paragraph (1) letter a, the Financial Services Authority will provide recommendations for registration by the business activities of the Operator.

Paragraph (3) If the results of the trial have a status of improvement, the Financial Services Authority may provide an extension of the period of no more than 6 (six) months from the date of the stipulation of status.

Paragraph (4) if the results of a status trial are not recommended, the Operator cannot re-submit the same IKD.

Paragraph (5) An Operator that is not recommended as referred to in paragraph (4) is excluded from the registration as an Operator.

Regulation of the Board of Governors No 19/14 / PADG / 2017, Article

17 Paragraph (2) In the event that the trial is declared successful, the Financial Technology Operator is prohibited from marketing products, services, technology, and / or business models that are tested before applying for a permit and / or approval in accordance with Bank Indonesia regulations governing the processing of payment transaction. 
Paragraph (5) if trials are declared unsuccessful in products, services, technology, and / or business models including Financial Technology in the payment system category, Financial Technology Providers are prohibited from marketing products and/or services and using the tested technology and/or business models.

Paragraph (6) if trials are declared unsuccessful in products, services, technology, and/or business models including Financial Technology in the payment system category, Financial Technology Providers are prohibited from marketing products and/or services and using the tested technology and/or business models.

Based on the explanation above, the differences in regulations regarding the Regulatory Sandbox between OJK and BI could cause one of the obstacles to Fintech's growth in Indonesia. There should be synchronisation with the provisions of the Regulatory Sandbox in Indonesia.

The mechanism for organising the regulatory sandbox by Bank Indonesia is as follows:

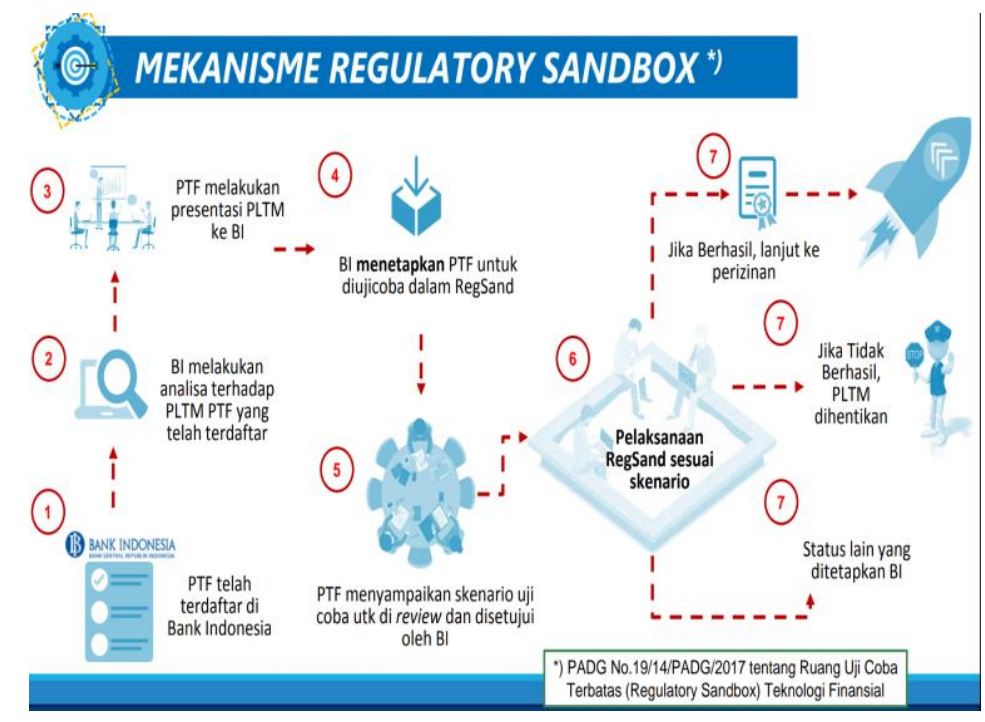

The existence of a legal system design for business actors is not in the form of new laws, but the form of policies such as directive or guidance so that structurally it does not disturb the existing legal order. Regarding fintech arrangements, there are two approaches offered by Julia Black, namely: principle-based and ruled-based. The Principle-based is largely chosen because the nature of the rules is very flexible, but unfortunately it is considered lacking in terms of legal certainty. Therefore, an alternative 
institution for resolving disputes over the financial ombudsman was established as a guardian of financial legal certainty. It shows that fast, cheap and efficient law enforcement instruments are legal requirements for business actors.

The fintech phenomenon teaches that the law must be able to follow the needs of the community, especially market participants and keep up with the developments of the times. Strengthening legal instruments also needs to be balanced and enhanced by legal institutions, so that the level of public trust in the rule of law is maintained. Because the business world requires high public trust so that the industry can grow and develop. With the completeness of legal instruments, the government can maintain a balance between national interests and the interests of business actors. ${ }^{8}$

The regulatory sandbox approach by Bank Indonesia and the Financial Services Authority is an effort to encourage the development of innovation in activities that use financial technology. As well as to face the development of Financial Technology, Bank Indonesia is committed to encouraging innovation while mitigating the risks that arise by creating a safe environment for innovation trials.

\section{The Efforts to Encourage the Growth of Financial Technology in Indonesia Through the Regulatory Sandbox Approach}

Unlimited technological developments in today's digital era, more complete with the presence of fintech. The term fintech is a financial service using a technology base which facilitates transactions that can do anywhere and anytime.

Financial technology (FinTech) is morphing into a larger field of the Internet of Thing (IO) and will be transformed exponentially in the coming decade by quantum computing. New asset classes and technologies are being created that will alter current business practice. ${ }^{9}$

Financial technology (fintech) is the application of information technology in the field of financial services. According to the National Digital Research Center, fintech is an innovation in financial services. Innovation, in this case, is a touch of modern technology that can bring financial transaction processes easier and more practical. It first appeared in 2004 which is a financial model from Zopa in the UK as a financial institution that operates as money lending service and subsequently a financial model that was introduced by Nakamoto in 2008. Fintech can be

\footnotetext{
${ }^{8}$ B Pratama, Perspektif Hukum Siber dalam Menangkap Fenomena Disruptive Innovation, Yogyakarta: Seminar Nasional Disruptive Innovation: Kajian Ekonomi dan Hukum, (2017).

${ }^{9}$ Carmen Leong, Barney Tan, Xioao Xiao, Felix Ter Chian Tan, Yuan Sun, "Nurturing a Fintech ecosystem: The case of youth microloan startup in China", Internasional Journal of Information Management (ELSEVIER), 37 (2), (2017), pp. 92-97.
} 
categorized into four types: Deposits, Lending, and Capital Rising; Market Provisioning; Payments, Clearing, and Settlement; and Investment and Risk Management. ${ }^{10}$

Fintech comes from the term Fintech derived from the term financial technology. According to The National Digital Research Center (NDRC), in Dublin, Ireland, defines fintech as "innovation financial services" or "innovation in financial services of fintech" which is an innovation in the financial sector that gets a touch of modern technology. Financial transactions through fintech include payment, investment, money lending, transfers, financial plans and financial product comparison. ${ }^{11}$

That based on Article 1 of Bank Indonesia Regulation No 19/12 / PBI / 2017 on the Implementation of Financial Technology as meant by financial technology is the use of technology in the financial system that produces new products, services, technology and /or business models and can have an impact on monetary stability, financial system stability, and / or efficiency, smoothness, security and reliability of the payment system. The development of financial technology, on the one hand, has proven to bring benefits to consumers, business people, and the national economy, but on the other hand has potential risks which if not adequately mitigated can disrupt the financial system.

Based on Bank Indonesia Regulation No 19/12 / PBI / 2017 on the Implementation of Financial Technology, mentioning that the financial technology ecosystem needs to be continuously monitored and developed to support the creation of monetary stability, financial system stability, and payment systems that are efficient, smooth, safe, and reliable for support sustainable and inclusive national economic growth.

The Financial Technology in Indonesia consists of several product classifications. Among the offered are products that offer lending and crowdfunding services. Through applications that provide this service, people who need funds can simply create an account on the application provider of lending and crowdfunding services and upload information regarding the amount of funds needed, the purpose of using the funds, and other relevant information. On the other hand, parties who have surplus funds can only look at the "catalogue" of the applicant and choose one or several debtors. In this mechanism, generally the funding needs that are met are only short-term funding needs with varying interest rates. Some start-ups that provide this product include Investree, UangTeman, and Modalku. Other

${ }^{10}$ Kennedy, P. S. J, Literature Review: Tantangan terhadap Ancaman Disruptif dari Financial Technology dan Peran Pemerintah dalam Menyikapinya, (2), (2017), p. 175.

${ }^{11}$ Ernama Santi, "Pengawasan Otoritas Jasa Keuangan Terhadap Financial Technology (Peraturan Otoritas Jasa Keuangan Nomor 77/Pojk.01/2016", Diponegoro Law Journal, 6 (3), (2017), p. 217. 
products that are also being offered by FinTech start-ups are payment and remittance services. In general, this business model is based on cashless transactions. This electronic money can be stored as data in a card, QR Code, or mobile phone devices. So that customers can make transactions anytime, anywhere, without the need to bring cash. Dimo, Kartuku, Dompetku and Doku are a No of start-ups from Indonesia who are engaged in this field. In addition to providing payment services, many financial technology-based start-ups also offer investment management services. Not only serving investment products, these start-ups also provide information related to the capital market and various investment instruments, such as stocks and mutual funds. Stockbit and Bareksa are two pilot companies that provide these services.

Furthermore, there are also start-up companies that provide education and personal financial management services. This start-up offers a variety of commercial product information ranging from credit, savings, insurance and investment. Not only that, some start-ups also make it easy to make pure financial records. Some start-up companies that provide these services include Cekaja.com, Duitpintar, AturDuit and Jurnal. In addition to the various start-ups above, other start-ups are engaged in more specific financial services. For example, iGrow and TaniHub, a start-up that is involved in agricultural finance; Iwak, start-up that provides fisheries funding services; Jojonomic, which offers reimbursement management services; and the Privy ID that provides digital identity and signature features for various electronic transaction approvals. ${ }^{12}$

As for the Indonesian fintech and FSA Association, the distribution of fintech profiles illustrated in 2016 is as follows: $:^{13}$

12 Fitri Safira, 2016, Ekosistem FinTech di Indonesia, http://https://swa.co.id/swa/myarticle/ekosistem-fintech-di-indonesia, accessed on 21-06- 2019

13 M. D. Hadad, "Financial Technology (Fintech) di Indonesia", Public Lecture About Fintech, in Indonesia Banking School, 2017. 


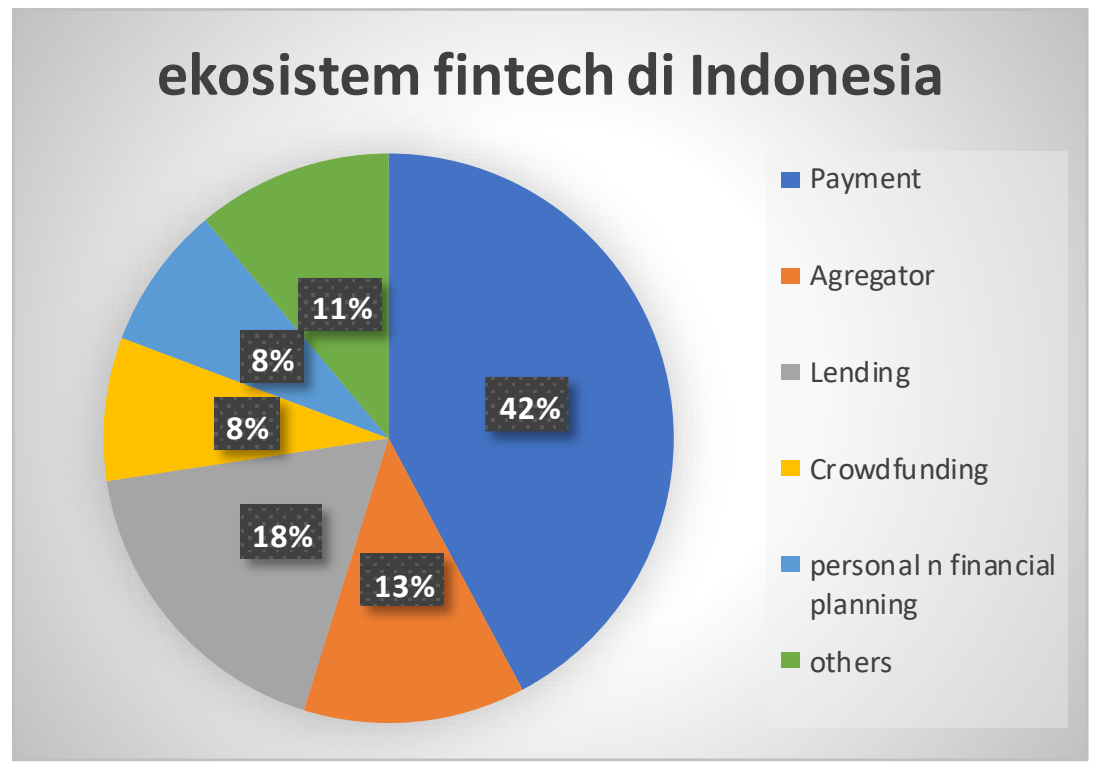

The development of fintech in Indonesia, which has been shown, requires handling, namely if FinTech Indonesia players are still dominant in the payment business (43\%), loans (17\%), and the remainder in the form of aggregators, crowdfunding and others. The amount of potential that is owned makes FinTech in need to be given space to grow. Adequate arrangements need to be made given the risks that might be caused.

The fintech industry is increasingly developing in various fields of financial services related to online transactions. The fintech industry is still relatively new in Indonesia, so financial literacy efforts are relevant to Fintech so that fintech's market share can optimally utilise online transaction facilities as well as regulations that guarantee the payment system for fintech enthusiasts, and protect against the risk of cybercrime. More over, it is synergizing with the existing financial industry to provide more benefits to consumers. As well as efforts to encourage the growth of financial technology in Indonesia through the regulatory sandbox approach, it can be done through appropriate policy setting to be able to drive the pace of innovation carried out by Financial Technology Providers while still applying the principles of consumer protection, risk management and prudence.

\section{Conclusion}

The regulatory sandbox approach by Bank Indonesia and the Financial Services Authority (OJK) is an effort to encourage the development of 
innovation in activities that use financial technology. There are differences in regulations regarding the Regulatory Sanbox between OJK and BI that cause one of the obstacles to Fintech's growth in Indonesia. There should be synchronisation with the provisions of the Regulatory Sandbox in Indonesia.

Efforts to encourage the growth of financial technology in Indonesia through the regulatory sandbox approach can be done through appropriate policy setting to be able to promote the pace of innovation carried out by Financial Technology Providers while still applying the principles of consumer protection, risk management and prudence.

\section{A. Book}

\section{Bibliography}

Ivo Jenik and Kate Lauer. (2017). Regulatory Sandboxes and financial Inclusion, Working Paper. Washington, D.C: CGAP.

Kennedy, P. S. J. (2017). Literature Review: Tantangan terhadap Ancaman Disruptif dari Financial Technology dan Peran Pemerintah dalam Menyikapinya. (2).

Pratama, B. (2017). Perspektif Hukum Siber dalam Menangkap Fenomena Disruptive Innovation.Yogyakarta: Seminar Nasional Disruptive Innovation: Kajian Ekonomi dan Hukum.

\section{B. Journal}

Carmen Leong, Barney Tan, Xioao Xiao, Felix Ter Chian Tan, Yuan Sun. "Nurturing a Fintech ecosystem: The Case of Youth Microloan Startup in China", Internasional Journal of Information Management (ELSEVIER), $37 \quad$ (2), (2017), https://doi.org/10.1016/j.ijinfomgt.2016.11.006.

Ernama Santi, "Pengawasan Otoritas Jasa Keuangan Terhadap Financial Technology (Peraturan Otoritas Jasa Keuangan Nomor 77/Pojk.01/2016”, Diponegoro Law Journal, 6 (3), (2017).

\section{Regulations}

Board of Governors Member Regulation No 19/14/PADG/2017 on the Limited Technology Testing Room (Regulatory Sandbox) Financial Technology.

Financial Services Authority Regulation No. 13 / POJK.02/2018 on the Digital Financial Innovations in the Financial Services Sector.

Bank Indonesia Regulation No 19/12 / PBI / 2017 on the Implementation of Financial Technology. 


\section{World Wide Web}

Bambang Pratama, 2017 Mengenal Regulatory Sandbox Pada Fintech, Rubric of Faculty Members, Binus University Faculty of Humanities, https://business-law.binus.ac.id/2016/09/29/mengenal-regulatorySandbox-pada-fintech/.

Dea Chadiza Syafina, 2018, "Mengenal Regulatory Sandbox, Rahim dari Kelahiran Para Fintech", https://tirto.id/mengenal-regulatory-sandboxrahim-dari-kelahiran-para-fintech-cJpW.

Fitri Safira, 2016, Ekosistem FinTech di Indonesia, http://https://swa.co.id/swa/my-article/ekosistem-fintech-di-indonesia, accessed on 21-06- 2019.

M. D. Hadad, Financial Technology (Fintech) di Indonesia. Public Lecture on Fintech, in Indonesia Banking School, 2017.

https://economy.okezone.com/read/2019/01/29/320/2010778/67-perusahaanfintech-uji-kelayakan-untuk-dapat-izin-ojk .

https://www.fca.org.uk/publication/research/regulatory-sandbox.pdf, accessed in Bandar Lampung on 27 -07-2018. 